\title{
Haloechinothrix alba gen. nov., sp. nov., a halophilic, filamentous actinomycete of the suborder Pseudonocardineae
}

\author{
Correspondence \\ Wen-Jun Li \\ wjli@ynu.edu.cn \\ Chang-Jin Kim \\ changjin@kribb.re.kr
}

\author{
Shu-Kun Tang, ${ }^{1} \dagger$ Yun Wang, ${ }^{2}$ † Hua Zhang, ${ }^{3}$ Jae-Chan Lee, ${ }^{4}$ Kai Lou, ${ }^{2}$ \\ Chang-Jin $\mathrm{Kim}^{4}$ and Wen-Jun $\mathrm{Li}^{1}$
}
${ }^{1}$ The Key Laboratory for Microbial Resources of Ministry of Education, and Laboratory for Conservation and Utilization of Bio-resources, Yunnan Institute of Microbiology, Yunnan University, Kunming 650091, PR China
${ }^{2}$ Xinjiang Institute of Microbiology, Xinjiang Academy of Agricultural Science, Urumqi, Xinjiang, 830091, PR China
${ }^{3}$ The National Engineering Center for Research of Microbial Pharmaceuticals and New Drug Research and Development Center, North China Pharmaceutical Group Corporation, Shijiazhuang 050015, PR China
${ }^{4}$ Functional Metabolite Research Center KRIBB, 52 Eoeun-dong, Yuseong gu, Daejeon 305-806, Republic of Korea

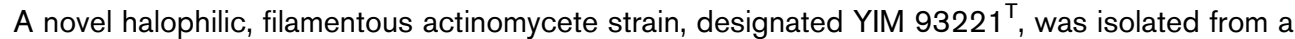
salt lake in Xinjiang province, north-west China, and subjected to a polyphasic taxonomic characterization. The isolate grew with 9-23\% (w/v) $\mathrm{NaCl}$ and did not grow without $\mathrm{NaCl}$. The isolate formed spiny aerial mycelium and did not form spores at maturity. The isolate contained meso-diaminopimelic acid as the diagnostic diamino acid and glucose, glucosamine, mannose and an unknown sugar as the major whole-cell sugars. The phospholipids were diphosphatidylglycerol, phosphatidylglycerol, phosphatidylethanolamine, phosphatidylinositol, phosphatidylinositol mannosides and an unknown phospholipid. $\mathrm{MK}-8\left(\mathrm{H}_{4}\right)$ was the predominant menaquinone. The major fatty acid was iso- $\mathrm{C}_{16: 0}$. The DNA G+C content was $68.1 \mathrm{~mol} \%$. Phylogenetic analysis based on 16S rRNA gene sequences indicated that strain YIM $93221^{\top}$ formed a distinct lineage within the suborder Pseudonocardineae and showed 91.9-94.8\% 16S rRNA gene sequence similarity with members of the suborder Pseudonocardineae. On the basis of the evidence from this polyphasic study, a novel genus and species, Haloechinothrix alba gen. nov., sp. nov., are proposed. The type strain of Haloechinothrix alba is YIM $93221^{\top}$ $\left(=\right.$ DSM $45207^{\top}=$ CCTCC AB $\left.208140^{\top}\right)$.
\end{abstract}

Since the first halophilic, filamentous actinomycete, Actinopolyspora halophila, was reported (Gochnauer et al., 1975), it has been known that some filamentous actinomycetes can grow with and tolerate high salt concentrations. However, in recent decades, only a few halophilic actinomycetes have been discovered and cultured, such as the genera Actinopolyspora and Streptomonospora (Cui et al., 2001) and some species belonging to the genera Nocardiopsis, Saccharomonospora and Prauserella. Recently,

†These authors contributed equally to this work.

The GenBank/EMBL/DDBJ accession number for the 16S rRNA gene sequence of strain YIM $93221^{\top}$ is GQ366705.

A micrograph of spiny aerial mycelium and a chromatogram of polar lipids of strain YIM $93221^{\top}$ are available as supplementary material with the online version of this paper. on the basis of extensive studies on the biological characteristics of halophilic filamentous actinomycetes, an efficient isolation medium, cellulose-casein-multisalts (CCMS) medium (Tang et al., 2008), was designed and used for the isolation of filamentous halophilic actinomycetes from hypersaline environments. By using this method, over 2000 halophilic actinomycete strains, which cannot grow without $\mathrm{NaCl}$ and have optimal growth with $10-15 \% \mathrm{NaCl}$, have been isolated from hypersaline soil in Xinjiang province in China. Phylogenetic analysis based on 16S rRNA gene sequences has revealed, in addition to the above-mentioned genera, two new genera, Haloactinospora (Tang et al., 2008) and Haloglycomyces (Guan et al., 2009), and three novel species, Amycolatopsis halophila (Tang et al., 2010), Saccharopolyspora halophila (Tang et al., 2009a) and Saccharopolyspora qijiaojingensis (Tang et al., 
2009c). Here, we report the characterization of another strain, designated YIM $93221^{\mathrm{T}}$.

Strain YIM $93221^{\mathrm{T}}$ was isolated from a soil sample collected from Qijiaojing Lake, which is a salt lake in Xinjiang Province, north-west China $\left(43^{\circ} 27^{\prime} \mathrm{N} 91^{\circ} 29^{\prime} \mathrm{E}\right)$, after 3 weeks of incubation at $37{ }^{\circ} \mathrm{C}$ on CCMS medium (Tang et al., 2008). Strain YIM $93221^{\mathrm{T}}$ was maintained on modified International Streptomyces Project (ISP) 4 agar containing $15 \%(\mathrm{w} / \mathrm{v}) \mathrm{NaCl}$ at $4{ }^{\circ} \mathrm{C}$ and as a glycerol suspension $(20 \%, \mathrm{v} / \mathrm{v})$ at $-20{ }^{\circ} \mathrm{C}$. Biomass for chemical and molecular studies was obtained by cultivation in ISP 4 without agar $(15 \%, \mathrm{w} / \mathrm{v}, \mathrm{NaCl} ; \mathrm{pH} 7.0)$ at $37^{\circ} \mathrm{C}$ and 150 r.p.m. for 1 week.

Cultural characteristics were determined after incubation for 3-4 weeks by methods given by the ISP (Shirling \& Gottlieb, 1966). All media were supplemented with $15 \%$ $(\mathrm{w} / \mathrm{v}) \mathrm{NaCl}$ for growth. The colours of substrate and aerial mycelia and any soluble pigments produced were determined by comparison with chips from the ISCC-NBS colour charts (Kelly, 1964). Growth was good on inorganic salts-starch agar (ISP 4) and oatmeal agar, moderate on Czapek's agar and nutrient agar and weak on glycerol/ asparagine agar; there was no growth on yeast extract-malt extract agar or potato agar. The aerial mycelium was white and the substrate mycelium was yellow-white (Supplementary Table S1, available in IJSEM Online). No soluble pigments were produced. Morphological characteristics of strain YIM $93221^{\mathrm{T}}$ were observed by light microscopy (model BH2; Olympus) and scanning electron microscopy (JSM 5600LV; JEOL) after incubation on ISP 4 agar and oatmeal agar containing $15 \%(\mathrm{w} / \mathrm{v}) \mathrm{NaCl}$ at $37{ }^{\circ} \mathrm{C}$ for 4 weeks. The substrate mycelium was well developed and fragmented into rod-like elements, while the aerial mycelium was 'hedgehog-like' or spiny. No spores were formed at maturity (Fig. 1 and Supplementary Fig. S1).

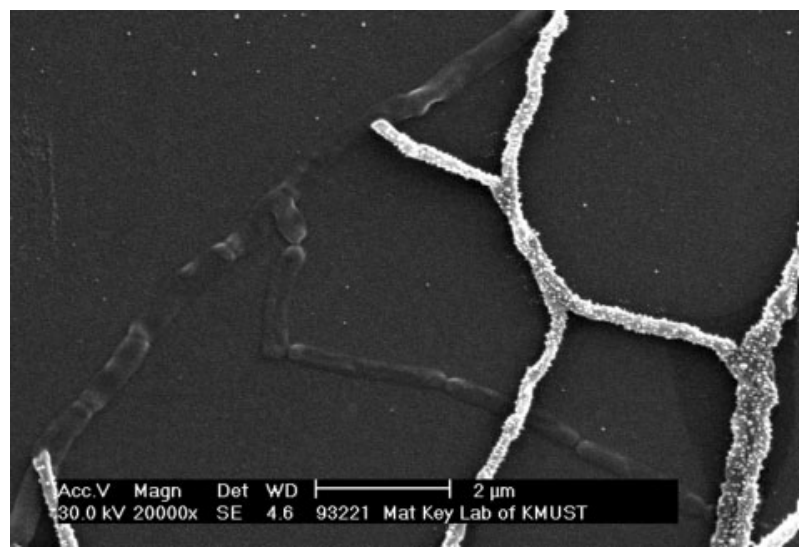

Fig. 1. Scanning electron micrograph of fragmented substrate mycelium and spiny or 'hedgehog-like' aerial mycelium of strain YIM $93221^{\top}$ grown on ISP $4(15 \% \mathrm{NaCl}, w / v)$ at $37{ }^{\circ} \mathrm{C}$ for 4 weeks. Bar, $2 \mu \mathrm{m}$.
Growth was tested at $5-55{ }^{\circ} \mathrm{C}$ (at intervals of $5{ }^{\circ} \mathrm{C}$ ) on ISP 4 containing $15 \%(\mathrm{w} / \mathrm{v}) \mathrm{NaCl}$ and at $0-30 \%(\mathrm{w} / \mathrm{v}) \mathrm{NaCl}$ (at intervals of $1 \%$ ) using ISP 4 as the basal medium. Growth was investigated at $\mathrm{pH} 4.0-10.0$ (at intervals of 1 $\mathrm{pH}$ unit) using the following buffer systems: $0.1 \mathrm{M}$ citric acid/0.1 M sodium citrate $(\mathrm{pH} 4.0-5.0), 0.1 \mathrm{M} \mathrm{KH}_{2} \mathrm{PO}_{4} /$ $0.1 \mathrm{M} \mathrm{NaOH}(\mathrm{pH} 6.0-8.0$ ) and $0.1 \mathrm{M} \mathrm{NaHCO} / 0.1 \mathrm{M}$ $\mathrm{Na}_{2} \mathrm{CO}_{3}$ ( $\mathrm{pH}$ 9.0-10.0). Media and procedures used for determination of physiological features and carbon source utilization were those described by Williams et al. (1989). Enzyme activity and acid production from carbohydrates were determined by using the API ZYM and API $50 \mathrm{CH}$ systems (bioMérieux) according to the manufacturer's instructions. Anaerobic growth was determined using the GasPak anaerobic system (BBL) according to the manufacturer's instructions. Strain YIM $93221^{\mathrm{T}}$ could grow at $20-45{ }^{\circ} \mathrm{C}$, at $\mathrm{pH} 4.0-8.0$ and with $9-23 \% \mathrm{NaCl}$, but could not grow in the absence of $\mathrm{NaCl}$, showing that strain YIM $93221^{\mathrm{T}}$ was a moderately halophilic actinomycete. The phenotypic and chemotaxonomic characteristics of strain YIM $93221^{\mathrm{T}}$ are distinctly different from those of other genera of the suborder Pseudonocardineae (Table 1). The detailed physiological and biochemical characteristics of strain YIM $93221^{\mathrm{T}}$ are given in the species description.

Isomers of diaminopimelic acid were analysed according to the procedures developed by Hasegawa et al. (1983). The whole-cell sugars were detected by HPLC after pre-column derivatization with 1-phenyl-3-methyl-5-pyrazolone (Tang et al., 2009b). Polar lipids were extracted and examined by two-dimensional TLC and identified using described procedures (Minnikin et al., 1984). Menaquinones were isolated according to Minnikin et al. (1984) and separated by atmospheric-pressure photoionization LC-MS (Tang et al., 2008). For fatty acid analysis, strain YIM $93221^{\mathrm{T}}$ was cultured on tryptic soy agar (Difco) containing $15 \% \mathrm{NaCl}$ at $37{ }^{\circ} \mathrm{C}$ for 7 days. Cellular fatty acid analysis was performed as described by Sasser (1990) using the Microbial Identification System (MIDI). Genomic DNA of strain YIM $93221^{\mathrm{T}}$ for the determination of $\mathrm{G}+\mathrm{C}$ content was prepared according to the method of Marmur (1961). The $\mathrm{G}+\mathrm{C}$ content of the DNA was determined by reversedphase HPLC of nucleosides according to Mesbah et al. (1989). Strain YIM $93221^{\mathrm{T}}$ contained meso-diaminopimelic acid as the cell-wall diamino acid, with glucose (47.2\%), glucosamine $(18.7 \%)$, mannose $(11.3 \%)$ and an unknown sugar $(11.3 \%)$ as the major whole-cell sugars; minor amounts of ribose $(6.9 \%)$ and galactose $(4.6 \%)$ were also detected. The phospholipids were diphosphatidylglycerol, phosphatidylglycerol, phosphatidylethanolamine, phosphatidylinositol, phosphatidylinositol mannosides and one unknown phospholipid (Supplementary Fig. S2). The predominant menaquinone was $\mathrm{MK}-8\left(\mathrm{H}_{4}\right)(95.4 \%)$, and a minor amount of MK-8 $\left(\mathrm{H}_{6}\right)(4.6 \%)$ was also detected. The cellular fatty acid profile contained major amounts of branched fatty acids and minor straight-chain and methyl fatty acids: iso- $\mathrm{C}_{14: 0}(1.2 \%), \mathrm{C}_{14: 0}(1.7 \%)$, iso$\mathrm{C}_{15: 0}(1.0 \%), \mathrm{C}_{15: 1} \omega 6 c(0.8 \%), \mathrm{C}_{15: 0}(2.7 \%)$, iso- $\mathrm{C}_{15: 1}$ 
Table 1. Differential phenotypic characteristics of strain YIM $93221^{\top}$ and the most closely related genera of the suborder Pseudonocardineae

Data for reference genera were obtained from Goodfellow et al. (1989), Korn-Wendisch et al. (1989), Korn-Wendisch et al. (1995), Tang et al. (2008) and Tian et al. (2009). +, Positive; -, negative; +/-, some species are positive and some are negative.

\begin{tabular}{|c|c|c|c|c|}
\hline Characteristic & Strain YIM $93221^{\mathrm{T}}$ & Sciscionella & Thermocrispum & Saccharopolyspora \\
\hline Aerial mycelium & Abundant & Sparse & Abundant & Abundant \\
\hline Spiny aerial mycelium & + & - & - & - \\
\hline Spores & - & - & + & + \\
\hline \multicolumn{5}{|l|}{ Growth in: } \\
\hline $0 \% \mathrm{NaCl}$ & - & + & + & $+1-$ \\
\hline $20 \% \mathrm{NaCl}$ & + & - & - & $+1-$ \\
\hline Temperature range $\left({ }^{\circ} \mathrm{C}\right)$ & $20-45$ & $10-37$ & $20-62.5$ & $10-63$ \\
\hline Whole-cell sugar type & $\mathrm{C}$ & A & $\mathrm{A}$ & A \\
\hline Major whole-cell sugars ${ }^{\star}$ & Glc, Man, GlcN, UK & Ara, Gal, Glc & Ara, Man, Glc & Ara, Gal \\
\hline Predominant menaquinone & $\mathrm{MK}-8\left(\mathrm{H}_{4}\right)$ & MK-9 $\left(\mathrm{H}_{4}\right)$ & MK-9 $\left(\mathrm{H}_{4}\right)$ & MK-9 $\left(\mathrm{H}_{4}\right)$ \\
\hline Phospholipids $\dagger$ & DPG, PG, PE, PI, PIM, PL & DPG, PC, PE, PME, PI, PL & PE, OH-PE, PI & DPG, PC, PE, PI, PIM \\
\hline Major fatty acid(s) $(>10 \%) \ddagger$ & $\mathrm{i}-\mathrm{C}_{16: 0}$ & $\mathrm{i}-\mathrm{C}_{16: 0}, \mathrm{i}-\mathrm{C}_{16: 0} 2-\mathrm{OH}$ & $\mathrm{i}-\mathrm{C}_{16: 0}$ & $\mathrm{i}-\mathrm{C}_{15: 0}, \mathrm{i}-\mathrm{C}_{16: 0}, \mathrm{i}-\mathrm{C}_{17: 0}$ \\
\hline DNA G $+C$ content $(\mathrm{mol} \%)$ & 68.1 & 69 & $69-73$ & $66.3-74$ \\
\hline
\end{tabular}

*Ara, Arabinose; Gal, galactose; Glc, glucose; GlcN, glucosamine; Man, mannose; UK, unknown sugar.

$\dagger$ DPG, Diphosphatidylglycerol; OH-PE, hydroxy-phosphatidylethanolamine; PC, phosphatidylcholine; PE, phosphatidylethanolamine; PG, phosphatidylglycerol; PI, phosphatidylinositol; PIM, phosphatidylinositol mannoside; PL, phospholipid; PME, phosphatidylethanolamine. $\ddagger \mathrm{i}$, Iso-branched.

$(2.3 \%)$, iso- $\mathrm{C}_{16: 0}(43.5 \%), \mathrm{C}_{16: 0}(8.6 \%), 10-$ methyl $\mathrm{C}_{16: 0}$ $(5.6 \%)$, iso- $\mathrm{C}_{17: 0}(0.8 \%)$, anteiso- $\mathrm{C}_{17: 0}(1.6 \%), \mathrm{C}_{17: 1} \omega 8 c$ (6.1\%), $\mathrm{C}_{17: 1} \omega 6 c(2.6 \%), \mathrm{C}_{17: 0}$ (3.5\%), 10-methyl $\mathrm{C}_{17: 0}$ (3.1\%), iso- $\mathrm{C}_{18: 0}(0.8 \%), \mathrm{C}_{18: 1} \omega 9 c(2.7 \%), \mathrm{C}_{18: 0}(1.8 \%)$, 10-methyl $\mathrm{C}_{18: 0}$ (tuberculostearic acid; $0.6 \%$ ) and $\mathrm{C}_{16: 1} \omega 7 c$ and/or iso- $\mathrm{C}_{15: 0} 2-\mathrm{OH}(8.1 \%)$. The $\mathrm{G}+\mathrm{C}$ content of the DNA was $68.1 \mathrm{~mol} \%$.

Extraction of genomic DNA and PCR amplification of the 16S rRNA gene were performed as described by Li et al. (2007). Multiple alignments with sequences from the most closely related members of the suborder Pseudonocardineae and calculations of sequence similarity were carried out using the EzTaxon server 2.1 (Chun et al., 2007). Phylogenetic analyses were performed using three treemaking algorithms: neighbour-joining (Saitou \& Nei, 1987), maximum-likelihood (Felsenstein, 1981) and maximum-parsimony (Fitch, 1971). A phylogenetic tree was constructed using the neighbour-joining method from $K_{\text {nuc }}$ values (Kimura, 1980) using MEGA version 4.0 (Tamura et al., 2007). The topology of the phylogenetic tree was evaluated by the bootstrap resampling method of Felsenstein (1985) with 1000 replicates.

The phylogenetic analysis based on 16S rRNA gene sequences revealed that strain YIM $93221^{\mathrm{T}}$ falls within the radius of the suborder Pseudonocardineae and has the highest sequence similarity to Saccharopolyspora rosea IMMIB L-1070 (GenBank accession no. AM992060; 94.8\%). The sequence similarity between strain YIM $93221^{\mathrm{T}}$ and members of other genera of the suborder Pseudonocardineae was 91.9-94.8\%. In the phylogenetic tree based on the neighbour-joining algorithm, strain YIM $93221^{\mathrm{T}}$ and Sciscionella marina SCSIO
$00231^{\mathrm{T}}$ (GenBank accession no. EU503139) formed a distinct clade supported by a high bootstrap value (66\%). This relationship was supported by the other tree-making methods used in this study (Fig. 2). All of the above data confirmed that strain YIM $93221^{\mathrm{T}}$ should be assigned to the suborder Pseudonocardineae.

Strain YIM $93221^{\mathrm{T}}$ was different from members of other genera of the suborder Pseudonocardineae in some morphological and physiological properties (Table 1): strain YIM $93221^{\mathrm{T}}$ was a halophilic actinobacterium that could grow with $23 \% \mathrm{NaCl}$ but not without $\mathrm{NaCl}$, whereas members of the genera Sciscionella, Thermocrispum and Saccharopolyspora (except Saccharopolyspora halophila and Saccharopolyspora qijiaojingensis) are non-halophilic actinomycetes that can grow without $\mathrm{NaCl}$ but not with $15 \% \mathrm{NaCl}$. Moreover, strain YIM $93221^{\mathrm{T}}$ exhibited some chemotaxonomic differences from the genera Sciscionella, Thermocrispum and Saccharopolyspora: strain YIM 93221 ${ }^{\mathrm{T}}$ had type $\mathrm{C}$ as the whole-cell sugar type (no diagnostic sugar), $\mathrm{MK}-8\left(\mathrm{H}_{4}\right)$ as the predominant menaquinone and phospholipids containing phosphatidylglycerol (no phosphatidylcholine), whereas members of the genera Sciscionella, Thermocrispum and Saccharopolyspora have type $\mathrm{A}$ as the whole-cell sugar type (arabinose and/or galactose as the diagnostic sugars), MK-9 $\left(\mathrm{H}_{4}\right)$ as the predominant menaquinone and phospholipids containing phosphatidylcholine (no phosphatidylglycerol).

Therefore, on the basis of phenotypic and phylogenetic differentiation of the new isolate, we propose that strain YIM $93221^{\mathrm{T}}$ represents a novel species of a new genus, Haloechinothrix alba gen. nov., sp. nov. 


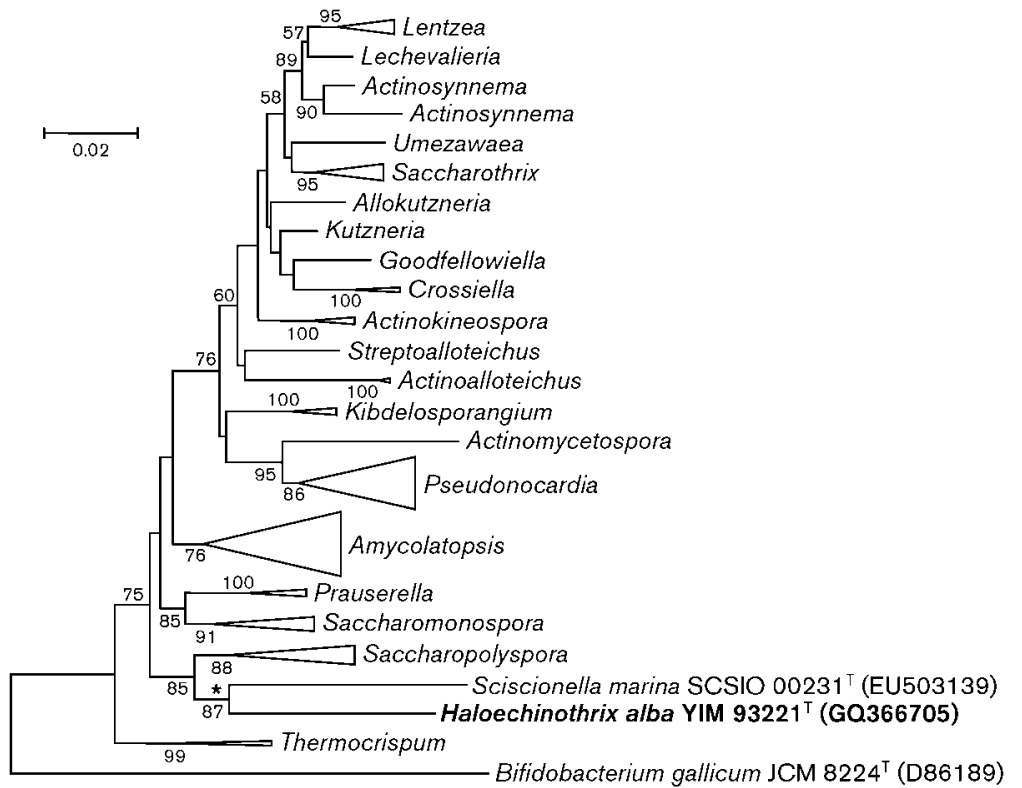

Fig. 2. Phylogenetic dendrogram obtained by distance-matrix analysis of 16S rRNA gene sequences, showing the position of strain YIM $93221^{\top}$ in the suborder Pseudonocardineae. Asterisks indicate that the corresponding node was also found in trees generated with the maximum-likelihood (Felsenstein, 1981) and maximum-parsimony (Fitch, 1971) algorithms. Bootstrap values (>50\%) based on 1000 replications are shown at branch nodes. Bifidobacterium gallicum JCM $8224^{\top}$ was used as an outgroup. Bar, $2 \%$ sequence divergence. Details of other sequences used to generate the tree are available in Supplementary Table S2.

\section{Description of Haloechinothrix gen. nov.}

Haloechinothrix (Ha.lo.e.chi.no'thrix. Gr. n. hals, halos salt; Gr. n. echinos hedgehog; Gr. fem. n. thrix hair; N.L. fem. n. Haloechinothrix halophilic, hedgehog-like filament, referring to halophilic filamentous actinomycetes with spiny aerial mycelium).

Gram-staining-positive, strictly aerobic, moderately halophilic, filamentous actinomycetes. Substrate mycelium fragments into rod-like elements and does not form chains of spores at maturity. Spiny aerial mycelium. The wholecell hydrolysates contain meso-diaminopimelic acid as the cell-wall diamino acid. Glucose, glucosamine, mannose and an unknown sugar are the major whole-cell sugars. The phospholipids are diphosphatidylglycerol, phosphatidylglycerol, phosphatidylethanolamine, phosphatidylinositol, phosphatidylinositol mannosides and an unknown phospholipid. The predominant menaquinone is MK$8\left(\mathrm{H}_{4}\right)$. The major fatty acid is iso- $\mathrm{C}_{16: 0}$. The $\mathrm{G}+\mathrm{C}$ content of the genomic DNA is about $68 \mathrm{~mol} \%$. The type species is Haloechinothrix alba.

\section{Description of Haloechinothrix alba sp. nov.}

Haloechinothrix alba (al'ba. L. fem. adj. alba white).

Exhibits the following properties in addition to those given in the genus description. Aerial mycelium is white and substrate mycelium is yellow-white on most tested media. No diffusible pigments are produced. Grows at $20-45{ }^{\circ} \mathrm{C}$ (optimum $37^{\circ} \mathrm{C}$ ), at $\mathrm{pH} 4.0-8.0$ (optimum $\mathrm{pH}$ 7.0) and with 9-23\% (w/v) $\mathrm{NaCl}$ (optimum $15 \% \mathrm{NaCl}$ ). Starch and Tweens 20, 40, 60 and 80 are degraded, but aesculin, casein, cellulose, chitin and urea are not. Negative for gelatin liquefaction, nitrate reduction, milk peptonization and coagulation and $\mathrm{H}_{2} \mathrm{~S}$ and melanin production. With API
ZYM, positive for esterase (C4), esterase lipase (C8), leucine arylamidase, valine arylamidase, cystine arylamidase and naphthol-AS-BI-phosphohydrolase, but negative for alkaline phosphatase, lipase (C14), $\alpha$-fucosidase, $\alpha$-galactosidase, $\beta$-galactosidase, $\beta$-glucuronidase, $\alpha$-glucosidase, $\beta$-glucosidase, $\alpha$-mannosidase, $N$-acetyl- $\beta$-glucosaminidase, trypsin and $\alpha$-chymotrypsin. Utilizes D-mannose, rhamnose, trehalose, erythritol, dulcitol, xylitol, starch, trisodium citrate, L-lysine, alanine, L-arginine, L-asparagine, glycine, L-histidine, L-proline, L-serine, L-threonine, L-tyrosine and hypoxanthine as sole carbon or nitrogen sources, but not D-arabinose, cellobiose, D-fructose, galactose, D-glucose, lactose, maltose, raffinose, D-ribose, sucrose, D-xylose, glycerol, inositol, mannitol, sorbitol, sodium acetate, sodium propionate, adenine, methionine, L-phenylalanine or xanthine. With API $50 \mathrm{CH}$, does not produce acid. The DNA G $+\mathrm{C}$ content of the type strain is $68.1 \mathrm{~mol} \%$.

The type strain is YIM $93221^{\mathrm{T}}\left(=\mathrm{DSM} 45207^{\mathrm{T}}=\right.$ CCTCC $A B 208140^{\mathrm{T}}$ ), isolated from a salt lake in Xinjiang province, north-west China.

\section{Acknowledgements}

This research was supported by the National Basic Research Program of China (2010CB833800), the National Natural Science Foundation of China (30860002 and 30870005), the Key Project of International Cooperation (2007DFB31620), the 973 Pre-research Program of China (2008CB417214), the Yunnan Provincial International Cooperative Program (2009AC017) and the 21C Frontier Program of Microbial Genomics and Applications from the MEST, Korea.

\section{References}

Chun, J., Lee, J.-H., Jung, Y., Kim, M., Kim, S., Kim, B. K. \& Lim, Y.-W. (2007). EzTaxon: a web-based tool for the identification of 
prokaryotes based on $16 \mathrm{~S}$ ribosomal RNA gene sequences. Int J Syst Evol Microbiol 57, 2259-2261.

Cui, X. L., Mao, P. H., Zeng, M., Li, W. J., Zhang, L. P., Xu, L. H. \& Jiang, C. L. (2001). Streptomonospora salina gen. nov., sp. nov., a new member of the family Nocardiopsaceae. Int J Syst Evol Microbiol 51, 357-363.

Felsenstein, J. (1981). Evolutionary trees from DNA sequences: a maximum likelihood approach. J Mol Evol 17, 368-376.

Felsenstein, J. (1985). Confidence limits on phylogenies: an approach using the bootstrap. Evolution 39, 783-791.

Fitch, W. M. (1971). Toward defining the course of evolution: minimum change for a specific tree topology. Syst Zool 20, 406-416.

Gochnauer, M. B., Leppard, G. G., Komaratat, M. K., Novitsky, T. \& Kushner, D. (1975). Isolation and characterization of Actinopolyspora halophila, gen. et sp. nov., an extremely halophilic actinomycete. Can J Microbiol 21, 1500-1511.

Goodfellow, M., Lacey, J., Athalye, M., Embley, T. M. \& Bowen, T. (1989). Saccharopolyspora gregorii and Saccharopolyspora hordei: two new actinomycete species from fodder. J Gen Microbiol 135, 21252139.

Guan, T.-W., Tang, S.-K., Wu, J.-Y., Zhi, X.-Y., Xu, L.-H., Zhang, L.-L. \& Li, W.-J. (2009). Haloglycomyces albus gen. nov., sp. nov., a halophilic, filamentous actinomycete of the family Glycomycetaceae. Int J Syst Evol Microbiol 59, 1297-1301.

Hasegawa, T., Takizawa, M. \& Tanida, S. (1983). A rapid analysis for chemical grouping of aerobic actinomycetes. J Gen Appl Microbiol 29, 319-322.

Kelly, K. L. (1964). Inter-Society Color Council - National Bureau of Standards Color Name Charts Illustrated with Centroid Colors. Washington, DC: US Government Printing Office.

Kimura, M. (1980). A simple method for estimating evolutionary rates of base substitutions through comparative studies of nucleotide sequences. J Mol Evol 16, 111-120.

Korn-Wendisch, F., Kempf, A., Grund, E., Kroppenstedt, R. M. \& Kutzner, H. J. (1989). Transfer of Faenia rectivirgula Kurup and Agre 1983 to the genus Saccharopolyspora Lacey and Goodfellow 1975, elevation of Saccharopolyspora hirsuta subsp. taberi Labeda 1987 to species level, and emended description of the genus Saccharopolyspora. Int J Syst Bacteriol 39, 430-441.

Korn-Wendisch, F., Rainey, F., Kroppenstedt, R. M., Kempf, A., Majazza, A., Kutzner, H. J. \& Stackebrandt, E. (1995). Thermocrispum gen. nov., a new genus of the order Actinomycetales, and description of Thermocrispum municipale sp. nov. and Thermocrispum agreste sp. nov. Int J Syst Bacteriol 45, 67-77.

Li, W.-J., Xu, P., Schumann, P., Zhang, Y.-Q., Pukall, R., Xu, L.-H., Stackebrandt, E. \& Jiang, C.-L. (2007). Georgenia ruanii sp. nov., a novel actinobacterium isolated from forest soil in Yunnan (China), and emended description of the genus Georgenia. Int J Syst Evol Microbiol 57, 1424-1428.
Marmur, J. (1961). A procedure for the isolation of deoxyribonucleic acid from microorganisms. J Mol Biol 3, 208-218.

Mesbah, M., Premachandran, U. \& Whitman, W. B. (1989). Precise measurement of the $\mathrm{G}+\mathrm{C}$ content of deoxyribonucleic acid by highperformance liquid chromatography. Int J Syst Bacteriol 39, 159167.

Minnikin, D. E., O'Donnell, A. G., Goodfellow, M., Alderson, G., Athalye, M., Schaal, A. \& Parlett, J. H. (1984). An integrated procedure for the extraction of bacterial isoprenoid quinones and polar lipids. J Microbiol Methods 2, 233-241.

Saitou, N. \& Nei, M. (1987). The neighbor-joining method: a new method for reconstructing phylogenetic trees. Mol Biol Evol 4, 406425.

Sasser, M. (1990). Identification of bacteria by gas chromatography of cellular fatty acids. USFCC Newsl 20, 16.

Shirling, E. B. \& Gottlieb, D. (1966). Methods for characterization of Streptomyces species. Int J Syst Bacteriol 16, 313-340.

Tamura, K., Dudley, J., Nei, M. \& Kumar, S. (2007). MEGA4: molecular evolutionary genetics analysis (MEGA) software version 4.0. Mol Biol Evol 24, 1596-1599.

Tang, S.-K., Tian, X.-P., Zhi, X.-Y., Cai, M., Wu, J.-Y., Yang, L.-L., Xu, L.-H. \& Li, W.-J. (2008). Haloactinospora alba gen. nov., sp. nov., a halophilic filamentous actinomycete of the family Nocardiopsaceae. Int J Syst Evol Microbiol 58, 2075-2080.

Tang, S.-K., Wang, Y., Cai, M., Zhi, X.-Y., Lou, K., Xu, L.-H., Jiang, C.-L. \& Li, W.-J. (2009a). Saccharopolyspora halophila sp. nov., a novel halophilic actinomycete isolated from a saline lake in China. Int J Syst Evol Microbiol 59, 555-558.

Tang, S.-K., Wang, Y., Chen, Y., Lou, K., Cao, L.-L., Xu, L.-H. \& Li, W.-J. (2009b). Zhihengliuella alba sp. nov., and emended description of the genus Zhihengliuella. Int J Syst Evol Microbiol 59, 2025-2032.

Tang, S.-K., Wang, Y., Wu, J.-Y., Cao, L.-L., Lou, K., Xu, L.-H., Jiang, C.-L. \& Li, W.-J. (2009c). Saccharopolyspora qijiaojingensis sp. nov., a novel halophilic actinomycete isolated from a salt lake. Int J Syst Evol Microbiol 59, 2166-2170.

Tang, S.-K., Wang, Y., Guan, T.-W., Lee, J.-C., Kim, C.-J. \& Li, W.-J. (2010). Amycolatopsis halophila sp. nov., a halophilic actinomycete isolated from a salt lake. Int J Syst Evol Microbiol 60, 1073-1078.

Tian, X.-P., Zhi, X.-Z., Qiu, Y.-O., Zhang, Y.-Q., Tang, S.-K., Xu, L.-H., Zhang, S. \& Li, W.-J. (2009). Sciscionella marina gen. nov., sp. nov., a marine actinomycete isolated from a sediment in the northern South China Sea. Int J Syst Evol Microbiol 59, 222-228.

Williams, S. T., Goodfellow, M. \& Alderson, G. (1989). Genus Streptomyces Waksman and Henrici 1943, 339 ${ }^{\mathrm{AL}}$. In Bergey's Manual of Systematic Bacteriology, vol. 4, pp. 2452-2492. Edited by S. T. Williams, M. E. Sharpe \& J. G. Holt. Baltimore: Williams \& Wilkins. 